\title{
Effective Communication Strategies of Sustainable Hospitality: A Qualitative Exploration
}

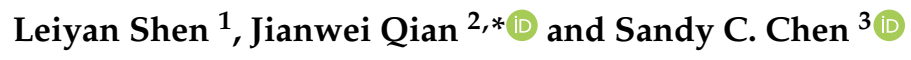 \\ 1 School of Foreign Languages, Zhejiang University City College, Hangzhou 310015, China; \\ shenly@zucc.edu.cn \\ 2 School of Economics and Management, Hangzhou Normal University, Hangzhou 311121, China \\ 3 The Hospitality and Tourism Program, Ohio University, Athens, OH 45701, USA; chens5@ohio.edu \\ * Correspondence: 821223168@163.com; Tel.: +86-571-28860716
}

Received: 21 July 2020; Accepted: 24 August 2020; Published: 26 August 2020

\begin{abstract}
Sustainability is a pivotal issue for the development of hospitality. The industry has attempted multiple ways to achieve this goal, with effective communication being one of the most prevalent ones. However, the communication effect which hospitality has obtained in terms of persuading customers to practice sustainability is imperfect. This study draws upon the communication literature and textually analyzes hospitality professionals' perception worldwide to generate a typology for hospitality practitioners to follow while conducting communication with customers on sustainability. The findings suggest two strategies and seven tactics that are of value to help hospitality achieve better communication. Thus, this study can extend the current communication theories on how to undertake sustainable hospitality communication and elucidate its operation in the industry.
\end{abstract}

Keywords: communication effect; qualitative exploration; strategies and tactics; sustainable hospitality; textual analysis

\section{Introduction}

Sustainability is currently a major pursuit in many industries, including tourism and hospitality. However, many business operators in hospitality feel nervous or refrain from taking sustainable action because, in their opinion, sustainability means that customers need to sacrifice conveniences, consequently lowering the customers' overall experience and reducing their satisfaction levels [1]. Additionally, in practice, hotel operators do receive complaints because customers believe hotels are saving money by asking them to reuse the towel or refrain from having their rooms cleaned [2]. For this group of customers, they are unable to associate what hotels are doing with the concept of sustainability and this influences their subsequent behavioral intention.

The existence of these abovementioned customers, both in concept and in reality, hinders hotels worldwide from furthering their sustainable initiatives to higher levels. Certain studies do provide evidence that modern customers are willing to pursue sustainability in their life to create a livable earth for future generations [3,4]. In hospitality, some customers even purposefully seek to stay in eco-friendly hotels. This tendency is increasing year by year [5]. This is especially evident for hotels situated in destinations where the environmental diversity is a primary attraction for tourists. Such a contrast between hoteliers and customers is, to a large extent, caused by insufficient communication between the two parties [6]. Hence, ineffective communication between hotels and customers exists and affects customer relationship management in hospitality, and consequently influences the realization of sustainable hospitality. 
The hotel industry has launched different voluntary initiatives to demonstrate their willingness and determination to promote sustainability ever since the 1990s, including the adoption of codes related to sustainable conduct, putting up eco-labels, and implementation of environmental management systems [7]. The hotel industry is frequently regarded as a utilizer of sustainability-focused operational strategies and practices [8]. Indeed, the hotel industry cannot move into the future if the industry does not incorporate resource conservation and sustainability into the core of the business culture [9], as pollution may damage the foundation for the industry's further development. Based on these facts, studies on sustainable hospitality have been listed as one of the hotspots in hospitality studies [10].

Customer relationship management has helped companies at various levels gain higher revenues and reduce operational costs, because managing this relationship well has been found to boost customer satisfaction effectively and efficiently [11]. Recently, companies in different industries have adopted diversified ways to assist their interaction with customers, and communication is among the most prevalent ways [12]. Concerning communication practices in sustainable hospitality, the communication of positive outcomes from the sustainable practice of hotels has been suggested as an integral part of marketing strategies to help hotels stand out in the competitive market [13]. Hence, communication should be integrated in customer relationship management to help hotels realize the goal of sustainable development. However, it is a challenging job for hotels to effectively communicate a sustainable image and encourage hotel customers to behave sustainably [14]. Studies demonstrate that if a business fails to communicate the intended information effectively, the results may go in the opposite direction $[15,16]$. This reversed situation is partially existent in the hotel industry already.

Therefore, it is high time that both academia and practitioners in hospitality work together to pinpoint effective measures to address the issue. Against this backdrop, the current study aims to generate a typology for hospitality practitioners to follow while conducting communication with customers on sustainability, instead of merely mentioning clichés and greenwashing. Consequently, the evidence-based principles in communication can help hotels establish a sustainable image among customers in an effective way, and win the customer's behavioral intention to book their hotel and practice sustainability during the stay. In other words, by elucidating how successful customer relationship management, in terms of practicing sustainable behavior in hotels can be sustained, this study can enhance customers' positive perception on hotels and gain their support for the sustainability campaign in the industry. Moreover, the findings of this study can also contribute to the development of communicative theories by investigating communicative principles in hospitality, a scarcely examined area in communication studies.

The rest of the study is structured as follows. Section 2 is allocated to a literature review and laying the theoretical foundation for this study. This is followed by an introduction of the research methods utilized in the study in Section 3. Section 4 presents the findings as well as the related discussion. This paves the way for the generation of both the theoretical and managerial implications of the study in Section 5. Section 5 also presents the conclusions of this study with a brief summary, and the suggested directions for future research.

\section{Literature Review}

\subsection{Sustainability Issues in Hospitality}

The rapid expansion of hotels has considerably contributed to the environmental degradation in many parts of the world, as hotels require a large amount of water and electricity for heating, cooling, and lighting, which can exert a negative influence on the environment [17]. This does not indicate that all hotels are destructive to the environment. This is because some hotels have undertaken environmental policies to specifically promote the preservation of the environment, in the hope of improving the quality of life of the community [18]. Typically, hotels have adopted measures to practice sustainability, including utilization of eco-friendly materials [19], water saving and reuse treatments [20], and the implementation of other energy saving programs [21]. Hotels mainly benefit 
from the implementation of sustainable practices in two perspectives, namely, the improvement of resource efficiency and savings in related energy consumption, and as a marketing tool to attract customers who are concerned about sustainability [22]. Previous studies also find a positive relationship between sustainable practices, and hotel customer satisfaction and loyalty [23].

The sustainability issue in hospitality has been extensively studied with a focus on the sustainable development of the industry, yet the influence of hotel operations is frequently ignored [24]. Studies find that while managers in the hotel industry have noticed the negative impact hotels have on the environment, they do not show sufficient commitment to mitigating these impacts [7,25]. The overall use of water and energy in the hospitality industry is still increasing rapidly throughout the world [26]. Hence, environmental change continues to be a major threat to the long-term operation and achievements of the hotel industry [27]. To address this issue, communication is considered as a way to effectively engage customers to follow sustainable guidance in hotels, and to help hotels better realize their goals in terms of sustainability [28].

\subsection{Customer Relationship Management in Hospitality}

As a fiercely competitive market, the hospitality industry has realized the importance of continuously improving the quality of service, to retain current customers, as well as the quality of customer relationship management [29]. Conventionally, hotels heavily rely on recognizing and keeping the customers that are most profitable and intend to develop a long-term relationship with them $[29,30]$. Evidence suggests that customer relationship management plays a vital role for hospitality, especially for chain hotels or hotels operating worldwide [31]. This is because successful relationship management can lead to positive reviews and generate customers' attachment to a particular hotel or hotel brand.

With the advancement in information technology, especially the rapid utilization of social media, customer relationship management has been increasingly reliant on this new technological tool. Hence, a new term "social customer relationship management" is used to represent this trend. It is defined as a business strategy established in a trusted environment to attract customers for participating in an active interaction, in the hope of achieving mutual benefit [32]. In hospitality, various strategies, patterns, and effects of social customer relationship management have been identified [32]. This has also been predicted as a medium to promote the long-term survival of the industry [33].

\subsection{Communication in Sustainability}

In conventional communication studies, the effort a company makes to communicate sustainability is termed as sustainability performance signaling [34]. Different motivations have been found regarding why companies are keen on taking such initiatives. These include building reputation and credibility for the companies, implementing benchmarking and performance assessment, and having desires for better management $[35,36]$. A frequently utilized method for this communication is to report what a company has done in this regard [37]. This has become an integrated part of many companies' annual report on corporate social responsibility [38].

With the advancement in information technology, websites are the key platform for different industries to communicate their sustainability [39]. Most literature finds that this is the prevalent mode in web-based sustainability communication, with a variation in the degree of website usage among different companies [40-42]. In addition, some studies indicate that more interactive methods, such as the use of emails and discussion forums have also been adopted to better communicate what companies have done in sustainability, and what they hope to improve [43,44]. Certain studies have been conducted to evaluate the online communication performance of different companies via surveys or interviews [42,45]. 


\subsection{Communicating Sustainability in Hospitality}

Sustainable communication is regarded as a fundamental strategy to increase hotels' competitiveness in the market. However, there are difficulties in its implementation [46]. In the hotel industry, the aforementioned information channel, the website, merely presents information about products and services that are crucial to a customer's behavioral intention to book [6]. The website does not often place an apparent emphasis on communicating hotel practices related to sustainability [47]. Hence, the major source for customers' information on sustainability in the hotel industry arises from customers' onsite observations and experiences, including reading from hotel booklets, observing the actual sustainable practices of the hotel staff, and sensing other eco-friendly signals posted by hotels [48].

Greenwashing is a form of communication used by hotels. It refers to the use of misleading or unconfirmed marketing claims regarding hotels' use of sustainable products, services, or technologies [49]. Greenwashing has been found to contribute to the reduction of customers' trust levels toward the hotel, as they will be sensitive and critical while perceiving the misleading information given out by the hotel [47]. Another issue existing in hotel sustainability communication is greenhushing. It is defined as under-communication regarding the hotels' sustainability [50]. This occurs when a hotel believes that customers may perceive their sustainability communication as purely a marketing strategy instead of a real practice for protecting the environment. Thus, the hotel chooses to communicate what it has done less frequently. Greenhushing even makes hotels with sustainability certificates hesitate to present the information, either on their websites or within any marketing material [51].

Evidently, proper communication of a hotel's sustainable image, as an important way to improve customer relationship, is likely to boost the development of the hotel. However, if the effect of the communication goes in the other direction, the hotel customers will fail to believe the hotel, or it may even diminish what the hotel has done in terms of sustainability. Hence, this kind of communication cannot shoulder the role of improving customer relationship as well as the sustainability goal of hotels. This indicates our research rationale to investigate the principles regarding how hotels can communicate their sustainability efforts effectively, and thereby address the current research gap. In this way, communication can fulfill its role of spreading proper information to the target audience. This can help both the business and the customer to be more eco-friendly and more willing to practice sustainability, at hotels as well as in their life. Thus, a more successful customer relationship can be established simultaneously, which in the long term is beneficial to the sustainable development of the industry. This effort has been made in one earlier research, which evaluates hotels' persuasive messages to promote hotel customers' green behavior, and finds that more research may be required to realize the intended goal. Hence, the current study attempts to address the same issue from a different perspective and research design. It is hoped that new insights can be gained to help the sustainable communication practice in hospitality.

\section{Methodology}

As previous studies mainly focus on the evaluation of the sustainability communication effects in the hotel context, this is among the first studies to rethink the basic principles that can help hotels do better in their communication to realize their goal of sustainability promotion while retaining a good relationship with customers. Accordingly, this study is, by nature, exploratory. Therefore, a qualitative approach is deemed appropriate to help realize the research objective. Specifically, textual analysis is utilized to examine the collected textual data for generating the principles on this type of communication.

All data are collected from the world panel section of the website hospitalitynet.org, which offers a social platform for both academia and practitioners in hospitality to share their views regarding prevalent topics. The hope is to generate usable advice to support the development of the industry. Numerous emergent topics in hospitality, including the human resource issue, the adoption of information technologies, and sustainable hospitality management, are frequently discussed. 
Hence, this platform can offer useful information to hospitality personnel to manage the hotel and its relationship with customers. On 24 January 2020, a post titled "How can sustainability be communicated beyond clichés and greenwashing?" was started by an expert to invite global opinions on this issue [2]. In total, 30 hospitality professionals worldwide have joined the discussion voluntarily. Hence, their perceptions on this specific communication issue should be authentic and appropriate to be used as the source of this study, which are presented in the textual format on the website. This lays the foundation for the subsequent textual analysis. The profiles of these respondents are listed in Table 1.

Table 1. Profiles of the professionals involved in sharing their opinion on the panel.

\begin{tabular}{|c|c|c|c|}
\hline No. & Gender & Position & Base \\
\hline 1 & Female & Vice president of a hotel group & UK \\
\hline 2 & Female & Director of a tourism company & UK \\
\hline 3 & Male & Senior staff of a hotel group & Germany \\
\hline 4 & Female & Chief commercial officer of an environmental agency & US \\
\hline 5 & Female & Founder of a sustainable hospitality consultancy & Germany \\
\hline 6 & Female & Expert for sustainability communication & Switzerland \\
\hline 7 & Male & Chief executive officer of an environmental consultancy & Thailand \\
\hline 8 & Female & Chief executive officer of a hotel group & Peru \\
\hline 9 & Male & Technology executive of a hotel consultancy & US \\
\hline 10 & Female & Founder of an environmental agency & Germany \\
\hline 11 & Female & Professor of tourism management & Spain \\
\hline 12 & Male & Founder of a sustainability leaders project & Switzerland \\
\hline 13 & Male & Chief executive officer of an investment consultancy & US \\
\hline 14 & Male & Assistant professor of hotel management & Switzerland \\
\hline 15 & Female & Director of a hotel sustainability consultancy & UK \\
\hline 16 & Male & Associate professor of corporate social responsibility & France \\
\hline 17 & Female & Chief executive officer of a hotel management consultancy & Germany \\
\hline 18 & Female & Professor of tourism management & Netherlands \\
\hline 19 & Male & Managing director of a technology company & US \\
\hline 20 & Male & Senior research fellow of sustainable hotel management & Netherlands \\
\hline 21 & Male & Managing director of an environmental consultancy & Germany \\
\hline 22 & Male & Managing director of an environmental consultancy & UK \\
\hline 23 & Male & Professor of hotel management & Germany \\
\hline 24 & Female & Senior staff of an environmental consultancy & US \\
\hline 25 & Female & Marketing director of a hotel & Austria \\
\hline 26 & Male & Lecturer of hotel management & Germany \\
\hline 27 & Male & Head of a hotel management consultancy & France \\
\hline 28 & Female & Head of a hotel management consultancy & UAE \\
\hline 29 & Male & Director of a hotel group & Germany \\
\hline 30 & Male & Founder of an environmental consultancy & Australia \\
\hline
\end{tabular}

Six participated professionals are from academia, five have different managerial positions at hotels, and the rest are working in different consultancy companies. Referring to the background of these professionals on the website, academics and consultants all have hotel working experience, and now change their role to contributing to the development of the industry. Hence, their opinion together with that from hospitality management can elucidate the hotel operation from another perspective, and is of high value for guiding the customer relationship management. Regarding the geographical distribution of these professionals, the majority are from Europe, while the other three continents also have a presence in the panel discussion, suggesting global participation on this topic. Thus, the textual data from this post is considered a good source for this study as global professionals participate in the discussion. All the perceptions on this issue are gathered to form a small corpus for further analysis in March 2020. In all, the size of the corpus is 7058 words, which is relatively small and more suitable for human involved textual analysis.

Textual analysis is a method to characterize textual data by distilling large amounts of text into their salient groupings of meaning following a strict coding process [52]. After one round of initial reading of 
the examined text, researchers are more familiar with the data. This is followed by designing a coding scheme specifically for this study, which is subsequently utilized to identify the information related to the research objective. Next, meaningful extraction is performed to prepare the final group of themes. Finally, a composite summary is obtained to address the research objective. During the coding and theming process, two researchers code and theme the data independently first. Whenever differences appear, the third researcher is invited to discuss emergent issues. The discussion lasts until the difference has been reconciled to guarantee the quality of the result in terms of comprehensiveness and clarity. The study uses human coding to do the textual analysis instead of computerized coding and analysis, mainly because human coding is better at identifying minor and easily overlooked themes. In this way, the obtained results are more convincing [53].

The diversified composition of the research team provides expertise from multidisciplinary fields, including linguistics, tourism, and management. All researchers have abundant academic research experience and industry practice. This suggests that the coded result of the study can meet the recognized criteria for credible qualitative research [54]. In the study, the data is collected systematically, the coding process is transparent, and reflectivity and intercoder reliability are applied.

\section{Findings and Discussions}

In all, seven tactics are universally acknowledged from both academia and the practitioners among the sampled professionals. After a careful classification, these seven tactics can be further categorized into two strategies: verbal and non-verbal communication strategies (Figure 1). The two types of strategies together with their seven tactics are presented hereafter. Meanwhile, only the typical quotes from the participated professionals are given while presenting each tactic.

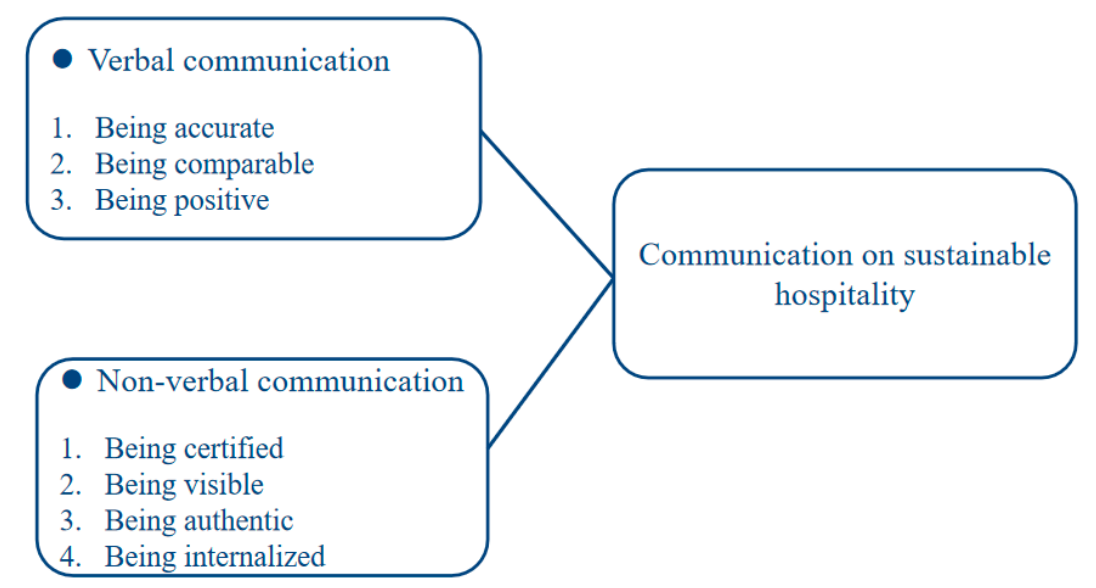

Figure 1. Strategies and tactics proposed by the professionals.

\subsection{Verbal Communication}

\subsubsection{Being Accurate}

It is found that hotels have increased utilization of some claims that are vague or non-specific, for example, the use of "eco-friendly", "green", and "a friend of nature" in hotels, and "regional", "local", and "from terroir" as adopted by restaurants [2]. The drawback of using ambiguous or non-standard language is that customers cannot establish a clear image regarding a sustainable action, as different words are chosen to represent it in various contexts, including business operation, marketing, and reporting. Hence, a lack of verified use of such terms may confuse customers, reducing the power of such sustainable communication. As is summed up by a professor in hospitality management,

"Claims being made must be verifiable so that the information communicated is accurate and not misleading or resulting in misinterpretation." (P23) 
Living in the internet era, customers can receive abundant information every day, increasing the difficulty for them to differentiate certain concepts if there is no universal standard to clarify them [55]. Therefore, certain standards should be established to help create a clear understanding of the concept. ISO 14021 [2], for example, is recommended for the uniformity of the words used to represent sustainability in the business context.

\subsubsection{Being Comparable}

Customers are, in general, becoming more proactive while making purchase decisions, as they are more willing to consume products and services that are aligned with the principle values they are adhering to [56]. Many customers are prone to being environmentally friendly. Hence, businesses, including the hotel industry, must find ways to express that they can meet customer expectations in this area. However, if hotels merely claim that they are green or eco-friendly, customers do not have any means to evaluate the actual performance of the hotel. Thus, it is better to make a comparison between the hotel and its competitors as well as between the hotel's current performance and its past. As the director of an energy and sustainability consultancy states,

"What \% energy and water reduction does your hotel/portfolio achieve compared to its relevant peers, and to past performance?" (P22)

This suggests the importance of being comparable while communicating hotels' sustainable performance and image. Only by comparison can a hotel learn about its deficiencies or gap, which gives the hotel a chance to reflect on what measures should be taken in order to catch up with the trend, and even establish an advantageous position in the market. Being comparable also indicates that hotels must compare what they did in the past with what they are doing now to demonstrate their progress.

"Communication on sustainability shall use data, baseline studies, and benchmark, allowing to measure evolution and prove the impact." (P27)

\subsubsection{Being Positive}

A common practice is for hotels to inform customers of their intent to protect the environment by presenting some negative figures related to climate change, such as the huge volume of carbon emission caused by hotel customers or water consumed by them daily [57]. Thus, customers may feel guilty or terrified after seeing these figures, which may stop them from taking certain actions to be environmentally friendly. However, the effect of using these terrifying figures is questioned in many studies $[6,58]$ because unconcerned customers pay little attention to these figures, while the concerned ones are psychologically forced to sacrifice the quality of their holiday to respond to these figures, which in turn reduces their satisfaction with the hotel. As commented below,

"People who are spending a significant part of their savings to travel do not want to feel guilty about it." (P19)

Hence, the proper method is for hotels to communicate positively, for example, telling customers that the energy they save at the hotel can be used to do other meaningful things, or how beautiful the world is going to look because of their energy conserving behavior at hotel. This positive communication is more acceptable among modern customers, while persuading them to pursue certain behavioral intentions [59].

\subsection{Non-Verbal Communication}

\subsubsection{Being Certified}

Using certifications has been found to be a useful tool in regulating practices among various industries, from the early ISO 9000 to the current industry and area specific certifications [60]. A call for 
certified green hotels has been proposed in different studies [61,62] and green certification is believed to have taken on two roles as is commented below,

"Certification and labels—whether legitimate or not-seems to be the marketing weapon of choice when it comes to communicating a hotel's sustainability efforts." (P26)

Evidently, hotels must meet certain requirements before being certified as green hotels, especially when this certificate is issued from an influential third party. Thus, certification can also act as a guide to regulate sustainable practices in the industry and stimulate hotels to practice sustainability. In return, the obtained certificate and related labels can represent the hotel's eco-friendly image and can be utilized as a marketing tactic.

\subsubsection{Being Visible}

Previously, hotels were fond of using signage to indicate they were taking eco-friendly actions to protect the environment, such as preparing a booklet in rooms or posting in certain areas of the hotel summarizing what the hotel has done regarding energy conservation. However, a mere statement about what the hotel has done may not successfully trigger customer sensational perceptions and, consequently, can only achieve a limited effect in communicating a hotel's green initiative. As indicated by a study, in communicating CSR practices in the business context, some simple explanation regarding what a company is doing is rather unlikely to attract customers' interest, and may fail to establish a responsible company image among customers [63]. The director of an organization in promoting sustainable hotel management states,

"The guest should see results of sustainable practices throughout the hotel, whether it is light sensors, passive shading, rainwater harvesting, use of native vegetation, protection of habitats, or locally sourced food and products." (P29)

This statement is also reflected by many other professionals both from industry and academia, suggesting its importance and the urgency in communicating a sustainable hotel image in a visible way. Hence, hotels need to visualize their actions to cater to this trend and satisfy the subsector of pro-environment customers.

Another visible way to communicate sustainability is to make the influence of customers' hotel living experience on the earth more transparent. The appearance of different technologies can help realize this aim, as a professor states,

"Conscious consumers need transparency. Wayaj has an advanced travel carbon footprint calculator and footprint offsetting program." (P11)

The communication done using these devices mediates the concerned customers to be eco-friendly. In other words, sometimes the signal sent out by non-humans is a useful facilitator for communication as well. Visibility can also be realized in another transparent manner, which is to inform customers of the progress as well as challenges the hotel is facing while implementing sustainability, just as follows,

"We find that our stakeholders are willing to understand this, as long as we're transparent about where we are on the journey, the challenges we face and what this means in reality." (P1)

In this way, customers can sense the sincere attitude of hotels practicing sustainability, and are more willing and cooperative to participate.

\subsubsection{Being Authentic}

It is not an easy task to persuade customers to sacrifice their convenience for the preservation of the environment, which is especially true of leisure tourists who mainly travel for relaxation, as convenience is valuable for them [64]. If customers are reluctant or feel forced to be eco-friendly, it will greatly reduce their positive perception of the hotel service. Thus, it is imperative for hotels to find a way to 
steer customers to willingly follow what hotels are proposing in terms of environmental protection. One useful way suggested by academia is to communicate the hotel's authenticity and genuine care about the earth and the whole population's well-being. For example, a hotel did the following,

"Every stay, a tree is planted. Provides a meaningful way for travelers to support the planting of trees/offset travel emissions while traveling." (24)

This indicates that authenticity can be reflected in what the hotels will actually do to allocate the energy or resources saved by customers. If customers can perceive a real effect, more customers can be transformed into eco-friendly consumers to support hotel and other industries' sustainable practice.

Furthermore, hotels should be truthful while providing sustainable information, especially when convenience is created for customers. For instance,

"Being able to explain to the 'informed traveler' why you still have a menu item that is not the best available option from a sustainability perspective, will create a more authentic story that have your employees trained to inform your guest that you comply with this or that standard." (P20)

In this case, the hotel does not use the menu item convenient for the customers, but the one beneficial to the environment. Hence, hotels must give further guidance to their employees to authentically transmit the intended sustainable message to customers to stimulate the customers' understanding and desired actions.

\subsubsection{Being Internalized}

In the business context, whenever a company intends to establish a certain image, it will frequently appoint their marketing team to design a marketing campaign to communicate the intended image [65]. However, this communication's first tendency has been found to be less influential or even harmful in many studies $[66,67]$. If customers cannot perceive what is communicated in the marketing campaign, their purchases will become a one-time only action and these companies will gradually lose their market share. If hotels intend to communicate sustainability, they should become sustainable first. In other words, communication should extend from the inside to the outside. Therefore, the managing director of a hotel group suggests,

"The world is more transparent than ever and if you focus on your employees and suppliers, this, in turn, will support and ensure exactly the communication you are looking for." (P21)

The behavior of the management team, the staff, and the supplier can be the authentic medium a hotel can rely on for communication, as the hotel's customers can easily perceive what hotel insiders are doing. If the insiders can demonstrate the hotel's deep-rooted sustainable image, the effect is bound to far exceed written words in hotel booklets or visual advertisements on television. Hence, internalized sustainability should come before any communicative campaign.

\subsection{Summary}

Previously, verbal communication has been regarded as the major medium for hotels to communicate their sustainable practices [50]. However, the findings of this study indicate several issues that should be highlighted while hotels are practicing this kind of communication. These include the accuracy of the language hotels use, the comparable results hotels need to show in their report or other written documents, and the positive use of persuasive communication. If hotels use diversified terms to represent sustainability, customers may be confused regarding what the hotel has done and what they, the customers, should do. If no clear information is shown regarding the progress the hotel has made in terms of sustainability, customers may not follow what the hotel is suggesting for sustainability. Finally, if negative words are used more frequently than positive ones, the quality of the 
customer's leisure and travel experiences may be reduced. Therefore, verbal communication is a must, but should be done with caution and guidance.

Regarding non-verbal communication strategies, four tactics have been identified. These include the utilization of certifications, the visibility and authenticity of a hotel's sustainable performance, and the internalization of a hotel staff's sustainable ideology and behavior. The first tactic is simple to realize, as the agency issuing the certificate has a standardized document to lead the hotel to certification, which is also a frequently utilized non-verbal communication tool at hotels. The visibility and authenticity tactics both require a hotel's effort in improving the transparency of what they have done. Mere verbal expressions on sustainability cannot affect experienced customers and may even cause them to consider whether the actual objective is sustainability for the environment and the earth, or only sustainability of the business.

By showing the real performance, an important non-verbal communication form, customers can better perceive hotels' sustainable initiative and respond accordingly. Lastly, the internalization process is considered as a crucial representation of non-verbal communication. Staff are the direct and ultimate contacts with hotel customers, and if the ideology and behavior of the hotel staff can be sustainability-oriented, this will greatly improve the customer perceptions and establish the hotel's credibility in sustainability.

Segmentation is important for most businesses in marketing due to the diversified composition of customers [68]. This rule should be applied to communicate sustainable practices in hotels, as customer personalities, outlooks on the world, and expectations toward the hotel living experience are varied. Tourists are becoming more proactive in the decision-making process, and most are apt to consume products and services that meet their core values. For example, mid-class leisure tourists and luxury urban business tourists are bound to respond differently toward hearing the same message [69]. Accordingly, if hotels use only one single communicative method or content, it will be very difficult to achieve a satisfying result. In view of these facts, the combination of both verbal and non-verbal communication strategies is more suitable for the success of communication regarding hotel sustainability and performance, which in turn can enhance the management of customer relationship as well.

\section{Conclusions}

The current study utilizes textual analysis to explore effective methods for hotels to communicate their sustainability practices in the hopes of gaining the desired responses from customers. By collecting the opinions of professionals from both academia and industry, a small corpus composed of professional opinion quotes is established for subsequent manual textual analysis. As the corpus is relatively small, the researchers deem a manual analysis the most appropriate to find useful data for theming and the final analysis. In summary, two major strategies and seven subordinate tactics are identified as useful for sustainable communication of the hotel industry.

This study is among the first to collect global professionals' viewpoints on the urgent issue of hotel sustainability communications, which is pivotal to the current customer relationship management in the industry [70]. By doing this, this study can reflect the past borders and elucidate the global communication practices for hotel sustainability. This study reinforces the importance of both verbal and non-verbal communication for the realization of the objective, thereby suggesting that hoteliers should take both strategies into their communication practice to more likely realize their intended goal. This study is among the scant ones to address the sustainability practice in hospitality, from the communication perspective, by providing a complete typology that managers can use as a checklist to enrich their communication effort. This typology identifies how verbal and non-verbal communication can create the intended image and help realize the sustainability goals of the hotel industry. Though some strategies or tactics may seem obvious, they are frequently ignored by managers, in practice. Hence, they should be highlighted and operationalized in order to better guide hotel customers to act sustainably at hotels. 
To the best of our knowledge, this study is also among the few in tourism and hospitality research to address the communication issue from verbal and non-verbal strategies. Earlier studies include the examination of cross-cultural differences in tourism [71], the management of bilingual employees in hospitality [72], and the investigation of Muslim tourists' needs [73]. Hence, this study extends the use of these two strategies in a new communication area, tourism and hospitality. This also implies that academic experts should incorporate both into their research and teaching practice while addressing this issue. In addition, teachers working in different levels of tourism or hospitality institutes should be aware of the importance of these two strategies in communicating sustainable ideologies. These strategies can foster a prospective hotelier's abilities to communicate sustainability and consciousness in critical thinking, which is beneficial to students' long-term overall growth. Finally, if the sustainability communication at a hotel is successfully realized following the strategies proposed in the study, this will not only contribute to the long-term success of the business, but also contribute to the sustainability of every individual as well as the society as a whole.

Several drawbacks are noted in the current study. First, all the textual data are analyzed by researchers. Therefore, human bias cannot be completely eliminated. Second, due to the convenience sampling method, 30 hospitality professionals who participated in the forum discussion are chosen as the source of data. Although they are from different parts of the world, few are from eastern or developing countries. Thus, the application of the findings to these countries may be limited. Third, the usefulness and relative importance of each tactic and strategy should be further examined to help hotels better allocate their time and resources in promoting sustainability.

Author Contributions: Conceptualization, L.S. and J.Q.; methodology, L.S.; validation, J.Q.; formal analysis, L.S. and S.C.C.; writing-original draft preparation, L.S.; writing-review and editing, J.Q. and S.C.C.; funding acquisition, L.S. All authors have read and agreed to the published version of the manuscript.

Funding: This research was funded by Teaching Reform Project from Education Department of Zhejiang, grant number KG20160549.

Conflicts of Interest: The authors declare no conflict of interest.

\section{References}

1. Ge, H.; Chen, S.; Chen, Y. International alliance of green hotels to reach sustainable competitive advantages. Sustainability 2018, 10, 573. [CrossRef]

2. Hospitality.net. Available online: Hospitalitynet.org/panel/125000036.html (accessed on 12 March 2020).

3. Buffa, F.; Franch, M.; Rizio, D. Environmental management practices for sustainable business models in small and medium sized hotel enterprises. J. Clean. Prod. 2018, 194, 656-664. [CrossRef]

4. Cvelbar, L.; Grun, B.; Dolnicar, S. Which hotel guest segments reuse towels? Selling sustainable tourism services through target marketing. J. Sustain. Tour. 2017, 25, 921-934. [CrossRef]

5. Booking.com. Available online: globalnews.booking.com/bookingcom-reveals-key-findings-from-its-2019sustainable-travel-report (accessed on 15 March 2020).

6. Ettinger, A.; Grabner-Krauter, S.; Terlutter, R. Online CSR communication in the hotel industry: Evidence from small hotels. Int. J. Hosp. Manag. 2018, 68, 94-104. [CrossRef]

7. Kang, K.; Stein, L.; Heo, C.; Lee, S. Consumers' willingness to pay for green initiatives of the hotel. Int. J. Hosp. Manag. 2012, 31, 564-572. [CrossRef]

8. Melissen, F. Sustainable hospitality: A meaningful notion? J. Sustain. Tour. 2013, 21, 810-824. [CrossRef]

9. Berezan, O.; Raab, C.; Yoo, M.; Love, C. Sustainable hotel practices and nationality: The impact on guest satisfaction and guest intention to return. Int. J. Hosp. Manag. 2013, 34, 227-233. [CrossRef]

10. Xu, X.; Gursoy, D. Influence of sustainable hospitality supply chain management on customers' attitudes and behaviors. Int. J. Hosp. Manag. 2015, 49, 105-116. [CrossRef]

11. Chen, I.; Popovich, K. Understanding customer relationship management (CRM): People, process and technology. Bus. Pros. Manag. J. 2003, 9, 672-688. [CrossRef]

12. Coltman, T.; Devinney, T.; Midgley, D. Customer relationship management and firm performance. J. Inf. Tech. 2011, 26, 205-219. [CrossRef] 
13. Ponnapureddy, S.; Priskin, J.; Vinzenz, F.; Wirth, W.; Ohnmacht, T. The mediating role of perceived benefits on intentions to book a sustainable hotel: A multu-group comparison of the Swiss, German and USA travel markets. J. Sustain. Tour. 2020, 28, 1290-1309. [CrossRef]

14. Tolkes, C. Sustainability communication in tourism-A literature review. Tour. Manag. Perspect. 2018, 27, 10-21. [CrossRef]

15. Coles, T.; Fenclova, E.; Diana, C. Tourism and corporate social responsibility: A critical review and research agenda. Tour. Manag. Perspect. 2013, 6, 122-141. [CrossRef]

16. Petts, J.I. Sustainable communication. Process Saf. Environ. Prot. 2000, 78, 270-278. [CrossRef]

17. Dimara, E.; Manganari, E.; Skuras, D. Don't change my towels please: Factors influencing participation in towel reuse programs. Tour. Manag. 2017, 59, 425-437. [CrossRef]

18. Abdel-Maksoud, A.; Kamel, H.; Elbanna, S. Investigating relationships between stakeholders' pressure, eco-control systems and hotel performance. Int. J. Hosp. Manag. 2016, 59, 95-104. [CrossRef]

19. Geerts, W. Environmental certification schemes: Hotel managers' views and perceptions. Int. J. Hosp. Manag. 2014, 39, 87-96. [CrossRef]

20. Fraj, E.; Matute, J.; Melero, I. Environmental strategies and organizational competitiveness in the hotel industry: The role of learning and innovation as determinants of environmental success. Tour. Manag. 2015, 46, 30-42. [CrossRef]

21. Tang, M.; Fu, X.; Cao, H.; Shen, Y.; Deng, H.; Wu, G. Energy performance of hotel buildings in Lijiang, China. Sustainability 2016, 8, 780. [CrossRef]

22. Chen, S.; Chen, H.; Zhang, K.; Xu, X. A comparison theoretical framework for examining learning effects in green and conventionally managed hotels. J. Clean. Prod. 2018, 174, 1392-1399. [CrossRef]

23. Han, H.; Lee, J.; Trang, H.; Kim, W. Water conservation and waste reduction management for increasing guest loyalty and green hotel practices. Int. J. Hosp. Manag. 2018, 75, 58-66. [CrossRef]

24. Nam, H.; Lo, A.; Yeung, P.; Hatter, R. Hotel ICON: Towards a role-model hotel pioneering sustainable solutions. Asia. Pac. J. Tour. Res. 2020, 25, 574-584. [CrossRef]

25. Su, Y.; Hall, C.; Ozanne, L. Hospitality industry responses to climate change: A benchmark study of Taiwanese tourist hotels. Asia Pac. J. Tour. Res. 2013, 18, 92-107. [CrossRef]

26. Wu, X.; Rajagopalan, P.; Lee, S. Benchmarking energy use and greenhouse gas emissions in Singpore's hotel industry. Energy Policy 2010, 38, 4520-4527. [CrossRef]

27. Reid, S.; Johnston, N.; Patiar, A. Coastal resorts setting the pace: An evaluation of sustainable hotel practices. J. Hosp. Tour. Manag. 2017, 33, 11-22. [CrossRef]

28. Preziosi, M.; Tourais, P.; Acampora, A.; Videira, N.; Merli, R. The role of environmental practices and communication on guest loyalty: Examining EU-Ecolabel in Portuguese hotels. J. Clean. Prod. 2019, 237, 117659. [CrossRef]

29. Wu, S.; Lu, C. The relationship between CRM, RM, and business performance: A study of the hotel industry in Taiwan. Int. J. Hosp. Manag. 2012, 31, 276-285. [CrossRef]

30. Sigala, M. Integrating customer relationship management in hotel operations: Managerial and operational implications. Int. J. Hosp. Manag. 2005, 24, 391-413. [CrossRef]

31. Luck, D.; Lancaster, G. The significance of CRM to the strategies of hotel companies. World. Hosp. Tour. Themes 2013, 5, 55-66. [CrossRef]

32. Chan, I.; Fong, D.; Law, R.; Fong, L. State-of-the-art social customer relationship management. Asia Pac. J. Tour. Res. 2018, 23, 423-436. [CrossRef]

33. Tung, V.; Au, N. Exploring customer experiences with robotics in hospitality. Int. J. Contemp. Hosp. Manag. 2018, 30, 2680-2697. [CrossRef]

34. Robinson, M.; Kleffner, A.; Bertels, S. Signaling sustainability leadership: Empirical evidence of the value of DJSI membership. J. Bus. Ethics 2011, 101, 493-505. [CrossRef]

35. Bellringer, A.; Ball, A.; Craig, R. Reasons for sustainability reporting by New Zealand local governments. Sustain. Account. Manag. Policy J. 2011, 2, 126-138. [CrossRef]

36. Constantinescu, M.; Orindaru, A.; Pachitanu, A.; Rosca, L.; Caescu, S.; Orzan, M. Attitude evaluation on using the neuromarketing approach in social media: Matching company's purposes and consumer's benefits for sustainable business growth. Sustainability 2019, 11, 7094. [CrossRef] 
37. Allen, M. Strategic Communication for Sustainable Organizations: Theory and Practice; Springer: Cham, Switzerland, 2016; pp. 1-10.

38. Baumgartner, R. Managing corporate sustainability and CSR: A conceptual framework combining values, strategies and instruments contributing to sustainable development. Corp. Soc. Responsib. Environ. Manag. 2014, 21, 258-271. [CrossRef]

39. Lodhia, S. Factors influencing the use of the World Wide Web for sustainability communication: An Australian mining perspective. J. Clean. Prod. 2014, 84, 142-154. [CrossRef]

40. Adelopo, I.; Moure, R.; Preciado, L.; Obalola, M. Determinants of web-accessibility of corporate social responsibility communications. J. Glob. Responsib. 2012, 3, 235-247. [CrossRef]

41. Cho, C.; Roberts, R. Environmental reporting on the internet by America's Toxic 100: Legitimacy and self-preservation. Int. J. Account. Inf. Syst. 2010, 11, 1-16. [CrossRef]

42. Lodhia, S. Web based social and environmental communication in the Australian minerals industry: An application of media richness framework. J. Clean. Prod. 2012, 25, 73-85. [CrossRef]

43. Rodriguez-Olalla, A.; Aviles-Palacios, C. Integrating sustainability in organizations: An activity-based sustainability model. Sustainability 2017, 9, 1072. [CrossRef]

44. Pavlov, O.; Melville, N.; Plice, R. Toward a sustainable email marketing infrastructure. J. Bus. Res. 2008, 61, 1191-1199. [CrossRef]

45. Herzig, C.; Godemann, J. Internet-supported sustainability reporting: Developments in Germany. Manag. Res. Rev. 2010, 33, 1064-1082. [CrossRef]

46. Hardeman, G.; Font, X.; Nawijn, J. The power of persuasive communication to influence sustainability holiday choices: Appealing to self-benefits and norms. Tour. Manag. 2017, 59, 484-493. [CrossRef]

47. Peng, N.; Chen, A. Luxury hotels going green-The antecedents and consequences of consumer hesitation. J. Sustain. Tour. 2019, 27, 1374-1392. [CrossRef]

48. Berezan, O.; Millar, M.; Raab, C. Sustainable hotel practices and guest satisfaction levels. Int. J. Hosp. Tour. Adm. 2014, 15, 1-18. [CrossRef]

49. Dief, M.; Font, X. The determinants of hotels' marketing managers' green marketing behavior. J. Sustain. Tour. 2010, 18, 157-174. [CrossRef]

50. Font, X.; Elgammal, I.; Lamond, I. Greenhushing: The deliberate under communicating of sustainability practices by tourism businesses. J. Sustain. Tour. 2017, 25, 1007-1023. [CrossRef]

51. Moriarty, J. Theorizing scenario analysis to improve future perspective planning in tourism. J. Sustain. Tour. 2012, 20, 779-800. [CrossRef]

52. McKee, A. Textual Analysis: A Beginner's Guide; Sage: Thousand Oaks, CA, USA, 2003; pp. 1-33.

53. Su, L.; Cacciatore, M.; Liang, X.; Brossard, D. Analyzing public sentiments online: Combining human- and computer-based content analysis. Inf. Commun. Soc. 2017, 20, 406-427. [CrossRef]

54. Arias, D.; Chen, T.; Moles, R. Educational interventions on fever management in children: A scoping review. Nurs. Open 2019, 6, 713-721. [CrossRef]

55. Malyuga, E.; McCarthy, M. English and Russian vague category markets in business discourse: Linguistic identity aspects. J. Pragmat. 2018, 135, 39-52. [CrossRef]

56. Richards, K.; Jones, E. Customer relationship management: Finding value drivers. Ind. Mark. Manag. 2008, 37, 120-130. [CrossRef]

57. Gossling, S.; Buckley, R. Carbon labels in tourism: Persuasive communication? J. Clean. Prod. 2016, 111, 358-369. [CrossRef]

58. Corner, A.; Randall, A. Selling climate change? The limitations of social marketing as a strategy for climate change public engagement. Glob. Environ. Chang. 2011, 21, 1005-1014. [CrossRef]

59. Tsao, W.; Hsieh, M. Exploring how relationship quality influences positive eWOM: The importance of customer commitment. Total. Q. Manag. Bus. Excel. 2012, 23, 821-835. [CrossRef]

60. Talib, M.; Chin, T.; Fischer, J. Linking Halal food certification and business performance. Br. Food J. 2017, 119, 1606-1618. [CrossRef]

61. Verma, V.; Chandra, B. Hotel guest's perception and choice dynamics for green hotel attribute: A mix method approach. Indian J. Sci. Technol. 2016, 9, 77601. [CrossRef]

62. Balaji, M.; Jiang, Y.; Jha, S. Green hotel adoption: A personal choice or social pressure? Int. J. Contemp. Hosp. Manag. 2019, 31, 3287-3305. [CrossRef] 
63. Oberseder, M.; Schlegelmilch, B.; Murphy, P. CSR practices and consumer perceptions. J. Bus. Res. 2013, 66, 1839-1851. [CrossRef]

64. Jani, D.; Han, H. Influence of environmental stimuli on hotel customer emotional loyalty response: Testing the moderating effect of the big five personality factors. Int. J. Hosp. Manag. 2015, 44, 48-57. [CrossRef]

65. Dowling, G. Developing your company image into a corporate asset. Long Range Plan. 1993, 26, 101-109. [CrossRef]

66. Sellnow, T.; Ulmer, R.; Snider, M. The compatibility of corrective action in organizational crisis communication. Commun. Q. 1998, 46, 60-74. [CrossRef]

67. Babcock, R. Du-Babcock, B. Language-based communication zones in international business communication. Int. J. Bus. Commun. 2001, 38, 372-412. [CrossRef]

68. Wedel, W.; Kamakura, W. Market Segmentation: Conceptual and Methodological Foundations, 2nd ed.; Springer: Cham, Switzerland, 2012; pp. 3-6.

69. Pennington-Gray, L.; Fridgen, J.; Stynes, D. Cohort segmentation: An application to tourism. Leis. Sci. 2003, 25, 341-361. [CrossRef]

70. Lee, S.; Oh, H. Effective communication strategies for hotel guests' green behavior. Cornell Hosp. Q. 2014, 55, 52-63. [CrossRef]

71. Reisinger, Y.; Turner, L. Cultural differences between Mandarin-speaking tourists and Australian hosts and their impact on cross-cultural tourist-host interaction. J. Bus. Res. 1998, 42, 175-187. [CrossRef]

72. Dawson, M.; Madera, J.; Neal, J. Managing bilingual employees: Communication strategies for hospitality managers. World. Hosp. Tour. Themes 2011, 3, 319-334. [CrossRef]

73. Oktadiana, H.; Pearce, P.; Chon, K. Muslim travelers' needs: What don't we know? Tour. Manag. Perspect. 2016, 20, 124-130. [CrossRef]

(C) 2020 by the authors. Licensee MDPI, Basel, Switzerland. This article is an open access article distributed under the terms and conditions of the Creative Commons Attribution (CC BY) license (http://creativecommons.org/licenses/by/4.0/). 